\title{
충수의 자궁내막증
}

\author{
김대현 ${ }^{1}$, 신동우 ${ }^{2}$ \\ ${ }^{1}$ 이앤김연합내과의원, ${ }^{2}$ 부강외과의원
}

\section{Endometriosis of the Appendix}

\author{
Dae Hyun Kim', Dong Wu Shin ${ }^{2}$ \\ ${ }^{1}$ Lee \& Kim Union Internal Medicine Clinic, Daegu; ${ }^{2}$ Bukang Surgical Clinic, Daegu, Korea
}

Endometriosis is the presence of ectopic endometrial tissue outside of the lining of uterine cavity. It is one of causes of chronic pelvic pain in women. Endometriosis of the appendix is rare and may present with acute or chronic abdominal pain. Preoperative diagnosis by ultrasonography is extremely difficult due to nonspecific findings. We report a case of endometriosis of the appendix who presented with recurrent episodes of right lower abdominal pain. Preoperative diagnosis was chronic appendicitis. Histopathologic examination of the appendix revealed endometriosis and chronic appendicitis. Endometriosis should be considered in the differential diagnosis of recurrent lower abdominal pain in fertile women especially with history of infertility

Keywords: Endometriosis; Appendix; Appendicitis; Ultrasonography

\begin{abstract}
서 론
충수의 자궁내막증은 가임기 여성의 급성 또는 만성적인 하 복부 통증의 원인 질환으로 드물게 보고되며[1] 비특이적인 초음 파 소견으로 인하여 수술 전 진단이 어렵다. 저자들은 2달 전부 터 지속된 간헐적인 우하복부 통증으로 내원한 중년 여성에서 초음파검사로 만성 충수염 내지 종양성 병변을 의심하여 시행한 수술 결과 충수의 자궁내막증으로 진단되었기에 보고한다.
\end{abstract}

\section{증 례}

53세 여자가 2달 전부터 시작된 재발되는 우하복부 통증을
주소로 내원하였다. 진찰상 경미한 우하복부 압통을 호소하 였다. 체온은 $36.5^{\circ} \mathrm{C}$ 로 정상이었고 혈액검사에서 백혈구(white

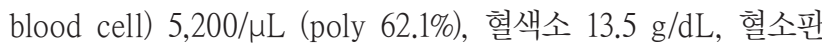
$192,000 / \mu \mathrm{L}$ 였다. 요검사에서 혈뇨 및 농뇨의 소견은 없었다.

복부 초음파검사(Acuson S1000; Siemens, Erlangen, Germa$\mathrm{ny})$ 에서 우하복부에 근위부 충수는 직경은 $4 \mathrm{~mm}$ 로 정상이었고 내강에 고에코의 공기 음영이 관찰되었으며(Fig. 1) 원위부에서 내강이 약간 좁아진 후 충수 말단부는 $5.5 \mathrm{~mm}$ 로 약간 확장되 어 있었고 충수벽의 비후가 관찰되었고 탐촉자로 압박되지 않았 다. 충수의 말단 부위의 원위부에 충수벽의 근육층과 연결되어 있는 저에코 병변과 주변에 고에코의 지방침착이 관찰되어 만성 충수염 또는 종양성 질환을 의심하였다(Fig. 2). 이 부위의 색도
Address for Correspondence: Dae Hyun Kim, M.D., Ph.D.

Lee \& Kim Union Internal Medicine Clinic, 2 Yulhadong-ro 23-gil, Dong-

gu, Daegu 41119, Korea

Tel: +82-53-964-3370, Fax: +82-53-964-3372

E-mail: pylori@empas.com
Received : 2017. 8.21

Revised : 2017.11.2

Accepted: 2017. 11. 9 
플러검사에서 혈류 증가는 관찰되지 않았다(Fig. 2). 환자의 경 우 이전의 타 병원에서 시행한 대장경검사와 복부 전산화단층촬 영(computed tomography)검사에서 정상 소견이었고 임상적으로 3주 이상의 만성적인 우하복부 통증이 지속되었으며 초음파검 사에서 급성 충수염의 소견에 부합하지 않아 만성 충수염 또는 종양성 질환 의심 하에 복강경하 충수절제술을 시행하였다. 수 술 결과 충수의 기저부는 정상이었고, 충수의 길이는 $6 \mathrm{~cm}$, 직 경은 $6 \mathrm{~mm}$ 였다. 두꺼워진 장막에 약간의 확장된 혈관이 관찰되

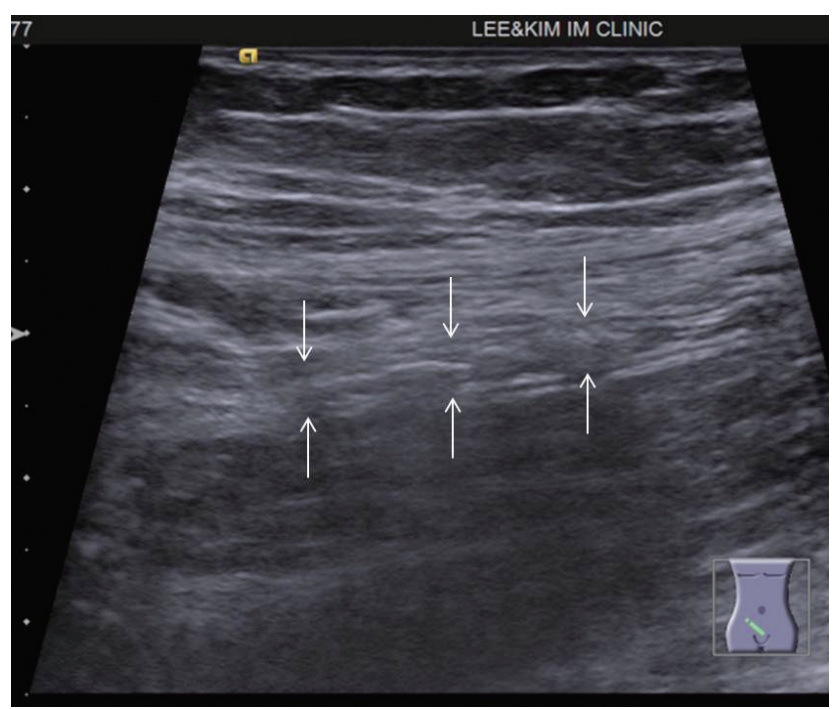

Figure 1. Ultrasonogram showed normal long axis view of the proximal appendix with intraluminal air (arrows, $4 \mathrm{~mm}$ in diameter, calipers not shown).
었으나 천공의 소견은 없었다(Fig. 3). 조직검사 소견은 충수벽에 만성 염증세포의 침윤과 충수벽의 섬유화가 있어 만성 충수염의 양상을 보였고 충수 말단부에 자궁내막증의 양상과 충수 내강 의 소실이 관찰되었다(Fig. 3). 이 환자에서 충수 말단에 위치한 자궁내막증 부위의 초음파 소견과 병리학적인 소견을 비교한 사 진이며 충수의 말단부, 자궁내막증 소견 그리고 충수 주위 지방 침착 부위를 잘 관찰할 수 있다(Fig. 4). 환자는 수술 후 우하복 부 통증이 많이 호전되었고 타 장기의 자궁내막증 유무 확인이 필요하여 부인과적인 진료를 시행하였고 정상으로 판명되었다.

\section{고 찰}

자궁내막증은 자궁 외에 자궁 내막 조직의 침착이 있는 질환 으로서 일반적으로 월경 곤란, 만성 골반통증 그리고 불임과 연 관이 된다[1].

자궁내막증의 빈도는 다양한데 한 연구에 의하면 불임으로 복 강경 시술을 받은 여성의 $20 \%$, 골반통을 호소하는 여성의 $24 \%$ 에서 동반되는 것으로 알려져 있다[2].

자궁내막증의 원인은 2 가지의 가설이 제시되고 있다. 첫째는 다능성 중간엽세포(multipotent mesenchymal cell)가 적절한 환 경에서 metaplasia가 일어나서 발생한다고 하고, 둘째는 다양한 자궁 내막세포가 생리혈 역류(retrograde menstruation) 중 난관 을 통해서 복강 내로 침착된다고 한다[3].

자궁내막증이 발생하는 흔한 부위는 난소(60-75\%), 자궁 천골
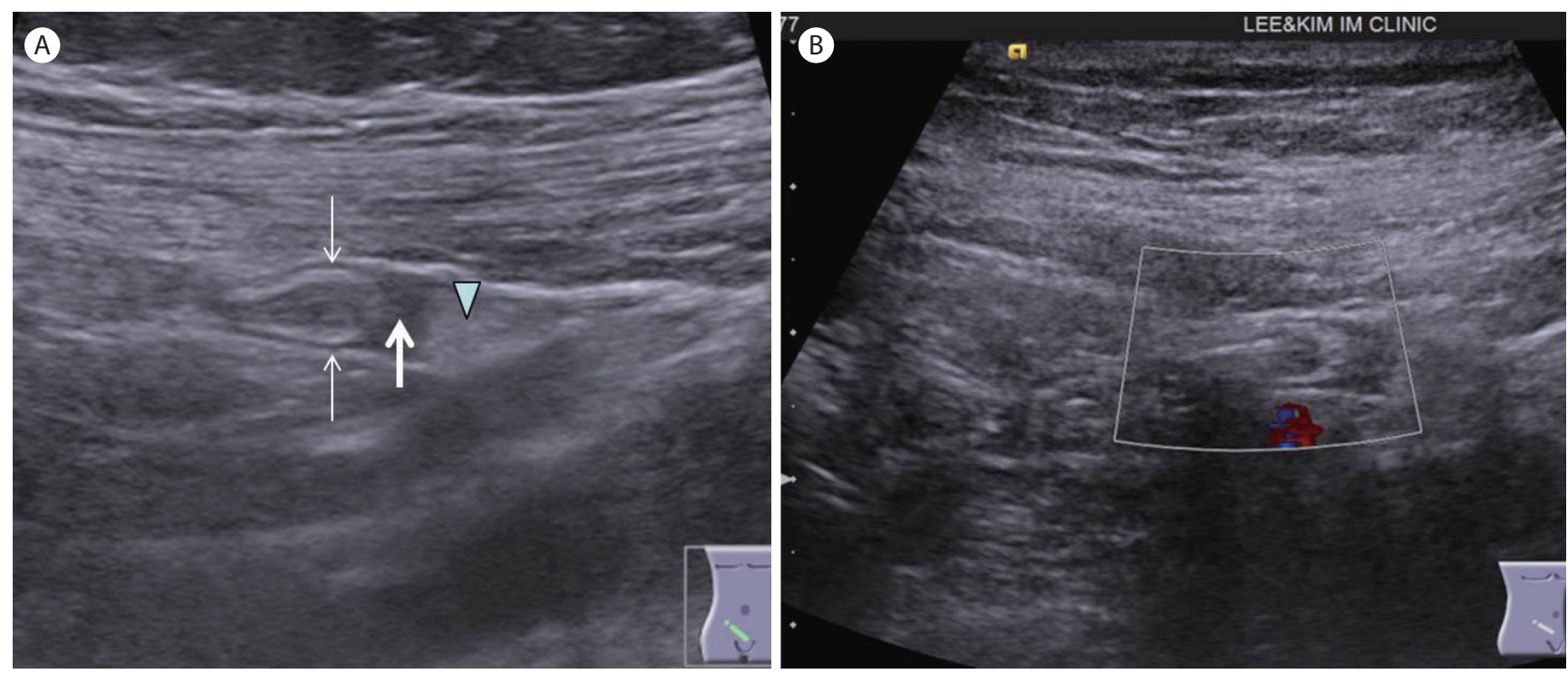

Figure 2. Abdominal ultrasonography. (A) Ultrasonogram showed distended distal end of the appendix (arrows, 5.5 mm in diameter, calipers not shown). Hypoechoic lesion (thick arrow) which is continuous with distal appendix with periappendiceal hyperechoic fat (arrowhead) was found. (B) Ultrasonogram did not show any increased vascularity in the distal appendix and periappendiceal hypoechoic lesion. 

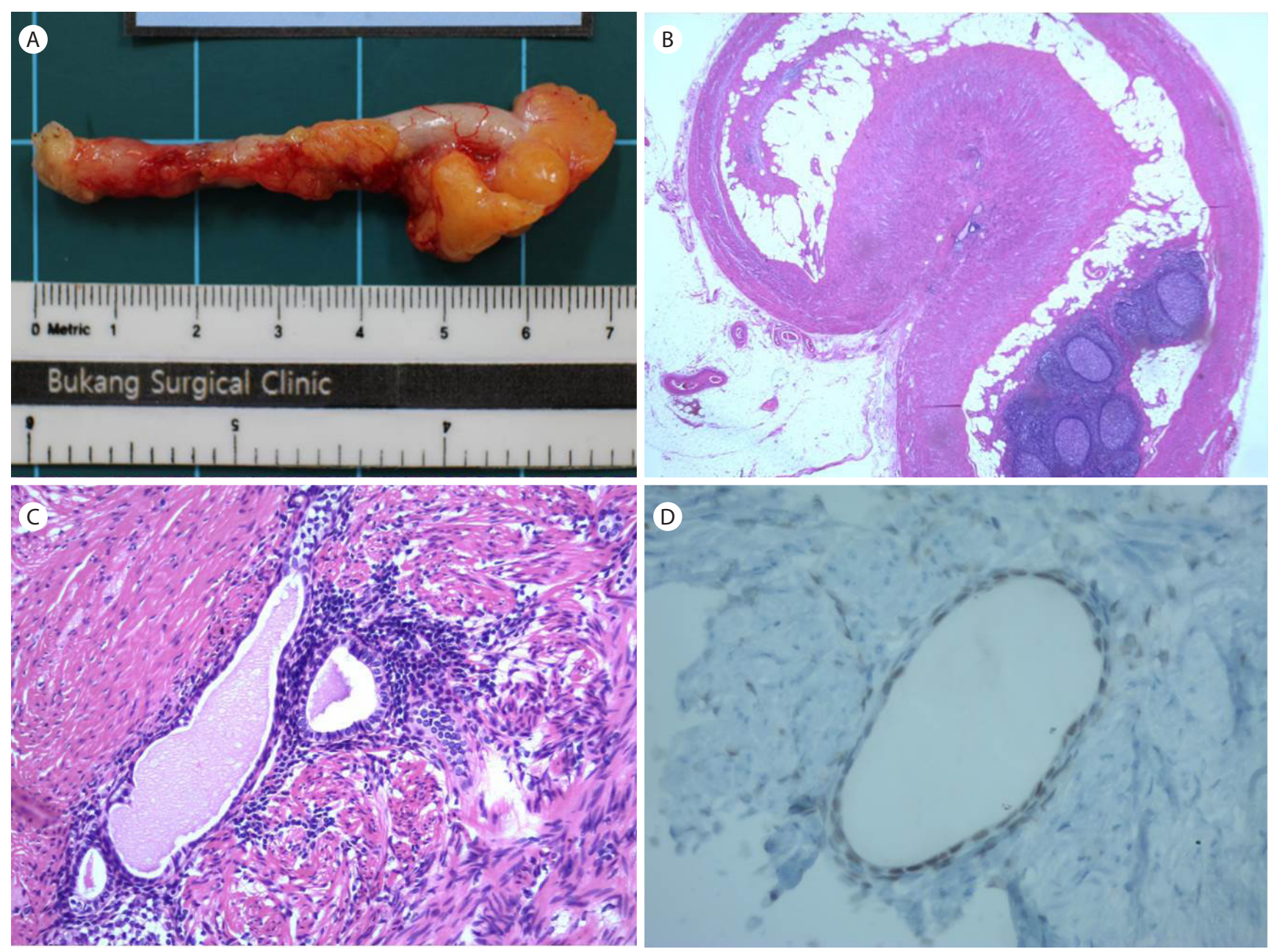

Figure 3. (A) Gross finding. Base of the appendix showed normal while body and tip of the appendix showed some engorged vessels with thickened serosa (about $6.5 \times 0.6 \mathrm{~cm}$ in size). (B) Microscopic findings. Endometriosis was found in the distal end of the appendix (H\&E, $\times 20)$. (C) Microscopic findings. Glandular epithelial and endometrial stromal components are present (H\&E, X200). (D) Microscopic findings. Darkly brown stained nuclei of epithelial cells of endometriosis foci showed positive reaction for estrogen receptors (Immunohistochemical stain for Estrogen receptor, $\times 400)$.

인대(uterosacral ligaments 30-65\%) 그리고 더글라스와(cul-de$\operatorname{sac} 20-30 \%)$ 이고 소화관에서는 3-37\%의 빈도로 관찰된다고 한 다[4]. 이 중 소화관에서는 직장구불결장부위(rectosigmoid region; 72\%), 직장질중경(rectovaginal septum; 13\%), 소장(7\%), 맹 장(4\%) 그리고 충수(3\%)의 빈도로 관찰된다[4].

충수의 자궁내막증은 1980년 von Rokitansky에 의해서 처음 기 술된 이후 여러 연구에서 0.8-22\%의 빈도로 보고되고 있다[4]. 1차 성과 2차성 형태로 구분되는데 1차성은 충수 외부의 자궁내막 증 소견 없이 충수 내에 국한된 자궁내막증이고, 2차성은 내부 또는 외부 자궁내막증과 연관되어 나타나는 형태를 말한다[4].

충수의 자궁내막증은 조직학적으로 충수 점막은 침범하지 않 고 대부분 근육층과 장막층이 침범된다. 침범된 충수는 호르몬
의 영향을 받아서 생리 중에 출혈을 하게 되고 충수의 부종과 염증으로 내강의 폐쇄가 오고 충수염의 증상이 나타나게 된다. 가임기 여성에서 생리 중인 경우에 급성 하복부 통증을 호소 한 다면 비록 그 증상이 명확하지 않더라고 이 질환을 의심해 볼 수 있겠다.

Yantiss 등[5]은 충수의 자궁내막증에 의한 증상과 병리학적 소견은 이러한 상처와 반복적인 재생 그리고 침착된 자궁 내막 조직의 생리에 의한 호르몬 변화에 기인한다고 하였다. 이러한 반복적인 염증으로 인하여 근육층의 비후와 섬유화가 동반되고 장관 협착과 장폐쇄가 동반되기도 한다.

충수의 자궁내막증의 증상은 일반적으로 무증상인 경우가 많 고 간혹 하복부 통증, 만성적인 골반 통증, 하부 장관 출혈, 장 


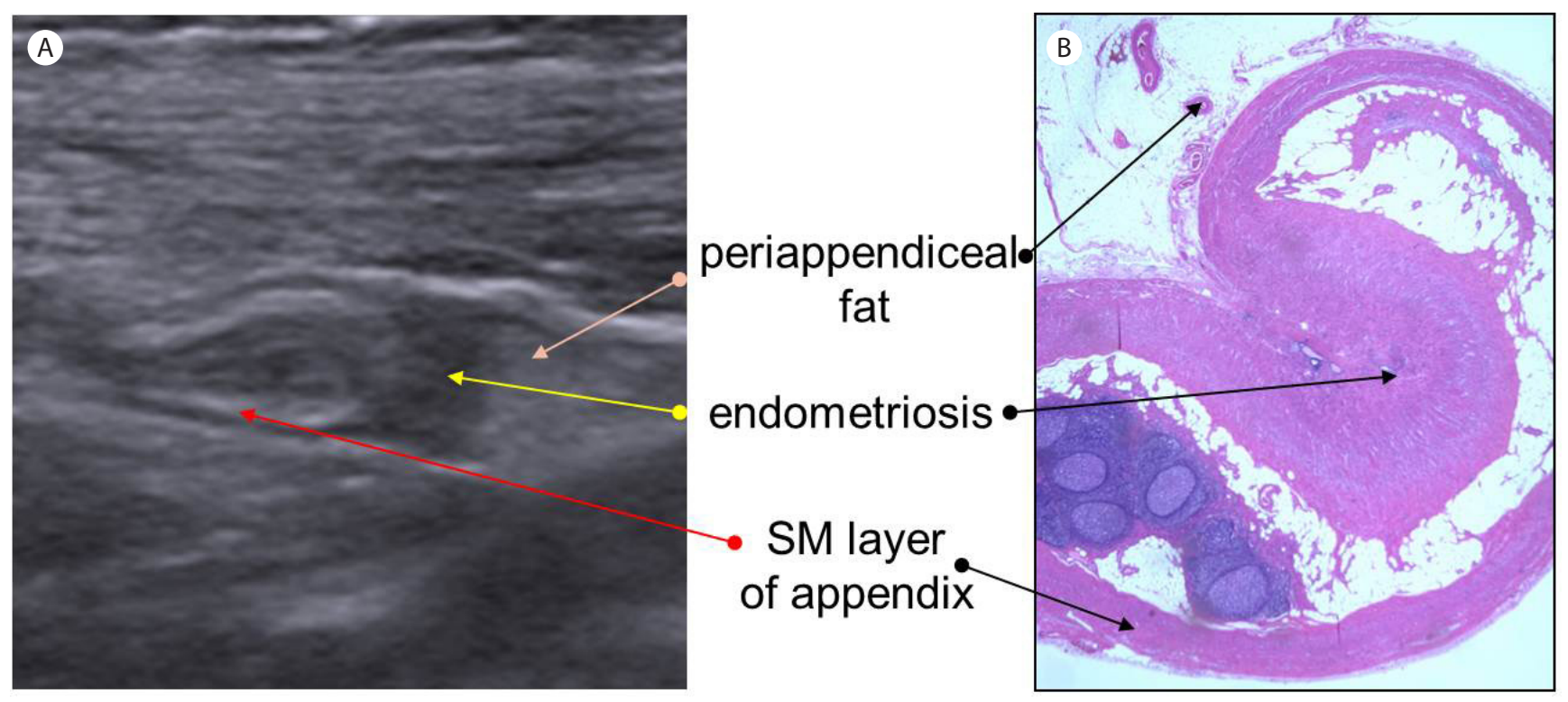

Figure 4. Comparison of ultrasonographic and microscopic findings of appendiceal endometriosis. (A) Ultrasonographic finding. (B) Microscopic finding. SM, submucosal layer.

중첩증, 천공 그리고 급성과 만성 충수염을 초래한다. 이처럼 다 양한 형태로 발현하므로 수술 전 진단은 어렵고 조직학적인 검 사로서 확진을 할 수 있다[4].

따라서 가임기 여성에서 충수염으로 진단되어 수술할 경우 특 히 이전에 자궁내막증이 있었거나 만성적인 골반 통증을 호소하 였거나 또는 생리와 연관된 증상이 있었다면 반드시 골반 부위까 지 확인하여 자궁내막증 유무를 확인하는 것이 중요하겠다.

소화관에서 발생하는 자궁내막증의 감별 진단은 염증성 장 질환, 장 게실염, 결핵성 장염, 양성과 악성 종양 그리고 허혈성 장염이 있으나 자궁내막증의 특징적인 방사선학적 소견이 없으 므로 확진은 복강경검사 또는 수술적 치료 후 조직학적 검사로 서 가능하다. 복강경검사에서 전형적인 자궁내막증의 복막 이식 (peritoneal implants) 소견은 다양한 착색과 섬유화를 동반하는 bluish-black 'powder-burn' 병변으로 보인다. 어두운 착색은 헤 모시데린 침착에 의한 것으로 보인다. 하지만 대부분의 경우 경 미한 비착색성 병변으로 보인다[4].

충수의 자궁내막증의 발생하는 위치는 반에서는 충수의 체부 이고 나머지 반은 충수의 말단부인데[6] 본 증례에서는 말단부에 서 발생하였다. 충수의 점막은 대부분 침범을 하지 않고 $2 / 3$ 에서 는 자궁내막증 소견이 근육층과 장막증에 위치하며 $1 / 3$ 에서는 장막층에만 위치한다[6]. 본 증례에서는 충수의 말단부의 근육 층과 연결되는 저에코성 병변으로 보였다.

병리학적으로 충수벽의 근육층과 장막층에 자궁 내막의 선조
직, 자궁 내막의 기질 그리고 출혈 소견 중에서 2가지가 관찰되 고, 그 외에도 섬유화, 점액화생(mucinous metaplasia) 신경주위 침범(perineural invasion), 골격근 재생(skeletal muscle regeneration) 등이 동반될 수 있다[7]. 충수에 발생하는 자궁내막증의 초 음파 소견은 낭성, 고형성, 복합성 병변이 있고 이 중에서 복합 성 병변이 가장 흔한 소견이다. 낭성 병변은 단순 낭종에서 처럼 매끈한 경계가 아니라 중격을 가지는 경계가 불규칙한 낭종으로 보인다[8]. 고형성 병변은 난소의 종양과 같은 양상으로 보이기도 하며 복합성 병변은 난관-난소 농양과 같은 염증성 병변으로 보 이기도 하는데 이러한 다양한 초음파 소견은 호르몬 반응에 따 른 자궁 내막 조직에서의 출혈과 섬유조직의 양과 분포에 의해 서 나타나게 된다[9]. 하지만 임상적으로 자궁내막증이 의심되면 초음파 소견에 상관없이 충수의 자궁내막증을 감별진단에 넣어 야 한다.

충수의 자궁내막증의 치료는 수술적 치료가 필요하고 증상이 있는 2 차성 충수 자궁내막증의 경우 수술적 치료 후 내과적인 호르몬치료가 필요하다[4]. 충수에 발생하는 자궁내막증의 경우 수술 전 진단이 어려우므로 가임기 여성에서 충수염의 임상적인 소견이 있으면 감별진단에 포함시켜야 하며 특히, 이전에 생리와 연관된 질환과 불임의 병력이 있거나 생리주기와 연관되는 반복 적인 우하복부 통증이 있었다면 의심해야 하겠다. 


\section{요 약}

자궁내막증은 자궁 외부에 자궁 내막 조직이 존재하는 질환 으로 여성에서 만성 골반 통증의 원인이다. 이 중에서 충수에서 발생하는 자궁내막증은 아주 드문 질환으로 급성 또는 만성적 인 하복부 통증의 원인 질환이다. 충수의 자궁내막증은 비특이 적인 초음파 소견으로 인하여 수술 전 진단이 어렵다. 저자는 평 소 만성적인 우하복부 통증을 호소하였던 여성에서 복부 초음 파검사에서 만성 충수염을 의심하여 수술적 치료 후 충수의 자 궁내막증을 진단하였던 예를 보고하는 바이다. 가임기 여성에서 반복적인 우하복부 통증이 있고 특히 통증이 생리와 연관되며 이전에 불임의 병력이 있었다면 충수의 자궁내막증을 의심할 수 있다.

중심 단어: 충수; 자궁내막증; 충수염; 복부 초음파

\section{REFERENCES}

1. Gustofson RL, Kim N, Liu S, Stratton P. Endometriosis and the appendix: a case series and comprehensive review of the literature. Fertil Steril 2006;86:298-303.

2. Eskanazi B, Warner ML. Epidemiology of endometriosis. Obstet Gynecol Clin North Am 1997;24:235-258.

3. Akbulut S, Sevinc MM, Bakir S, Cakabay B, Sezgin A. Scar endometriosis in the abdominal wall: a predictable condition for experienced surgeons. Acta Chir Belg 2010;110:303-307.

4. Emre A, Akbulut S, Yilmaz M, Bozdag Z. An unusual cause of acute appendicitis: appendiceal endometriosis. Int J Surg Case Rep 2013;4:54-57.

5. Yantiss RK, Clement PB, Young RH. Endometriosis of the intestinal tract: a study of 44 cases of a disease that may cause diverse challenges in clinical and pathologic evaluation. Am J Surg Pathol 2001;25:445-454.

6. Uncu H, Taner D. Appendiceal endometriosis: two case reports. Arch Gynecol Obstet 2008;278:273-275.

7. Woodward PJ, Sohaey R, Mezzetti TP Jr. Endometriosis: radiologic-pathologic correlation. Radiographics 2001;21:193-216; questionnaire 288-294.

8. Park SB, Kim JK, Cho KS. Sonography of endometriosis in infrequent sites. J Clin Ultrasound 2008;36:91-97.

9. Sandler MA, Karo JJ. The spectrum of ultrasonic findings in endometriosis. Radiology 1978;127:229-231. 